\title{
Increasing the Level of Social Protection of the Population: The Development Features of the Insurance Market of the Russian Federation
}

\author{
Svetlana Yanova $^{1 *}$, Olga Korobeynikova ${ }^{2}$, Nataliya Apatova ${ }^{3}$, Oleg Blazhevich ${ }^{3}$, Vlasta Shalneva ${ }^{3}$, \\ Amina Zharova ${ }^{3}$
}

\author{
${ }^{1}$ The St. Petersburg State University of Economics (UNECON), 21 Sadovaya str., St. Petersburg, 191023, Russia \\ ${ }^{2}$ Volgograd State Technical University, 28, Lenin Ave., Volgograd, 400005, Russia \\ ${ }^{3}$ V.I. Vernadsky Crimean Federal University, 4 Vernadskogo Avenue, Simferopol, 295007, Republic of Crimea, Russia
}

Received: 01/07/2020

Accepted: 29/09/2020

Published: 20/12/2020

\begin{abstract}
The relevance of the study of the insurance market is associated with the strengthening of its role in increasing the level of social protection of the population, increasing the volume of investments in the development of the state economy, as well as exempting the state budget from additional costs for reimbursing losses from unforeseen events. Without insurance market development, it is impossible to ensure the safety of the socio-economic development of the state, the continuity of the functioning of business actors, improving the population welfare and many other guarantees that compensate for the effects of the current risks of environment. The aim of the work is to determine the features of the development of the insurance market in Russia, as well as to identify problems and prospects of its functioning in order to increase the level of social protection of the population. We use modern general scientific and special research methods, including deduction, induction, analysis, synthesis, abstraction, generalization, system analysis, comparison. Currently, the Russian insurance market actively reformed in accordance development strategy; however, due to the crisis processes in the economy, the full implementation of measures is somewhat difficult. The conjuncture of the insurance market is quite sensitive to fluctuations of economy; therefore, in the future its development will depend on economic and political factors, external and internal threats. Many problems solution depends on the use of modern insurance technologies (InsurTech), which combine traditional insurance methods and IT innovations. New approaches require preliminary pilot implementation with subsequent scaling, and legal regulation, the development of digital law in Russia.
\end{abstract}

Keywords: Insurance market, Financial market, Socio-economic development, State, Security, State regulation

\section{Introduction}

The centuries-old experience in the formation of the insurance market of the Russian Federation proves the need for its study and improvement as the most important institution of economic development of society. The state and problems of development of OSAGO in the Russian Federation are analyzed [1], assessment of the cost of insurance companies [2], the role of auto insurance in the portfolio of insurance companies [3], analysis of the capital structure of insurance companies [4], the role of social insurance [5]. Currently, the insurance market designed to provide security, stability, social guarantees in society through a financial protection mechanism, and the development of the insurance market is one of the important strategic directions of the socio-economic policy of Russia [6-9]. The increasing role of the insurance market in raising the level of social protection of the population, increasing the volume of investments in the development of the economy, and exempting the state budget from expenses for reimbursement of losses from unforeseen events made this work relevant. A sufficient number of studies address the issues of achieving economic security [10-19]. They note that without a developed insurance market it is impossible to ensure the socio-economic development of the state, the stable functioning of business entities, the preservation and improvement of the welfare of the population [20-27]. The aim of the work is to determine the features of the development of the insurance market in Russia, as well as to identify problems and prospects of its functioning. In accordance with the goal, we solved the following tasks: (a) assessment of market conditions and its features in Russia at the present stage; (b) identification of problems and prospects for the development of the insurance market in Russia; and (c) forecast for the development of the insurance market.

The object of the study is the insurance market in the Russian Federation at the present stage of development, as well as the

Corresponding author: Svetlana Yanova, The St. Petersburg State University of Economics (UNECON), 21 Sadovaya str., St. Petersburg, 191023, Russia. E-mail: ya_s_yu@bk.ru 
processes taking place on it. The subject of the research is the current state and prospects for the development of the insurance market in Russia.

\section{Methods}

When writing the work, modern general scientific and special research methods used, in particular: deduction, induction, factor analysis, synthesis, abstraction, generalization, system analysis, comparison. Sources of information for writing the article: teaching and methodological aids, articles from scientific journals and collections of scientific papers in the field of insurance and electronic resources, statistical materials of the Central Bank of Russia. [28-33]. The factor analysis was also used. For this, data from literature sources were used to select indicators to determine the characteristics of the development of the insurance market in Russia, as well as to identify problems and prospects for its functioning to increase the level of social protection of the population.

\section{Researches Results}

At present, the Russian insurance market is in a difficult situation: insurers are under tremendous pressure from factors of other financial markets (stock market volatility, currency fluctuations, license reviews), and the difficult macroeconomic situation and the expansion of sanctions against Russia add uncertainty and risks. We begin the analysis of the insurance market in Russia with the dynamics of the volume of insurance premiums for all types of insurance, which during 2013 - 2017 showed a positive trend (Figure 1).

As noted above, insurance premiums for the analyzed period showed a positive trend. In particular, in 2017 insurance premiums increased by 98210007 thousand rubles compared 2016 and at the end of 2017 amounted to 1,278,841,595 thousand rubles. These changes significantly affected by the accelerated development of such types of insurance as life insurance, compulsory motor third-party liability insurance (OSAGO), voluntary medical insurance, auto insurance (KASKO), accident insurance and property insurance for legal entities. Let us analyze the dynamics of the volume of premiums by type of insurance in 2013 - 2017 (Figure 2).

Property insurance of legal entities has different dynamics in 2013 - 2017 years; it demonstrates an increase or decrease over the analyzed period. Insurance premiums on insurance of property of legal entities decreased by 11,497,832 thousand rubles in 2017 compared to 2016 year and amounted to 95988475 thousand rubles. Accident insurance as well as property insurance of legal entities has different dynamics in 2013 - 2017. The volume of insurance premiums for accident insurance in general increased by $27,483,463$ thousand rubles in $2013-2017$, as the increase in insurance premiums in 2014 and in 2016 - 2017 eliminates their decrease in 2015.

Auto insurance, insurance premiums as a whole for the analyzed period decreased by 49,811,111 thousand rubles, so their decrease in 2015 - 2017 exceeds their increase in 2014. Voluntary health insurance had a positive development trend in 2013 - 2017. The volume of insurance premiums increased as a whole by 25041781 thousand rubles for the analyzed period. The compulsory motor third-party liability premiums increased by $87,827,926$ thousand rubles in 2017 compared to 2013. The volume of these insurance premiums reached the highest value in 2016 (234 368827 thousand rubles), however this indicator slightly decreased in 2017. The volume of life insurance premiums has a positive trend in 2013 - 2017. It amounted to 331 536826 thousand rubles at the end of 2017, which is 115796662 thousand rubles more than in 2016. This increase in life insurance premiums was affected by the dynamics of life insurance premiums for death, surviving to a certain age or period, with the condition of periodic insurance payments and with the participation of the insured in the insurer's investment income (the so-called investment life insurance), as well as pension insurance $[34,35]$. Consider the structure of the insurance market for the main types of insurance premiums (Figure 3).

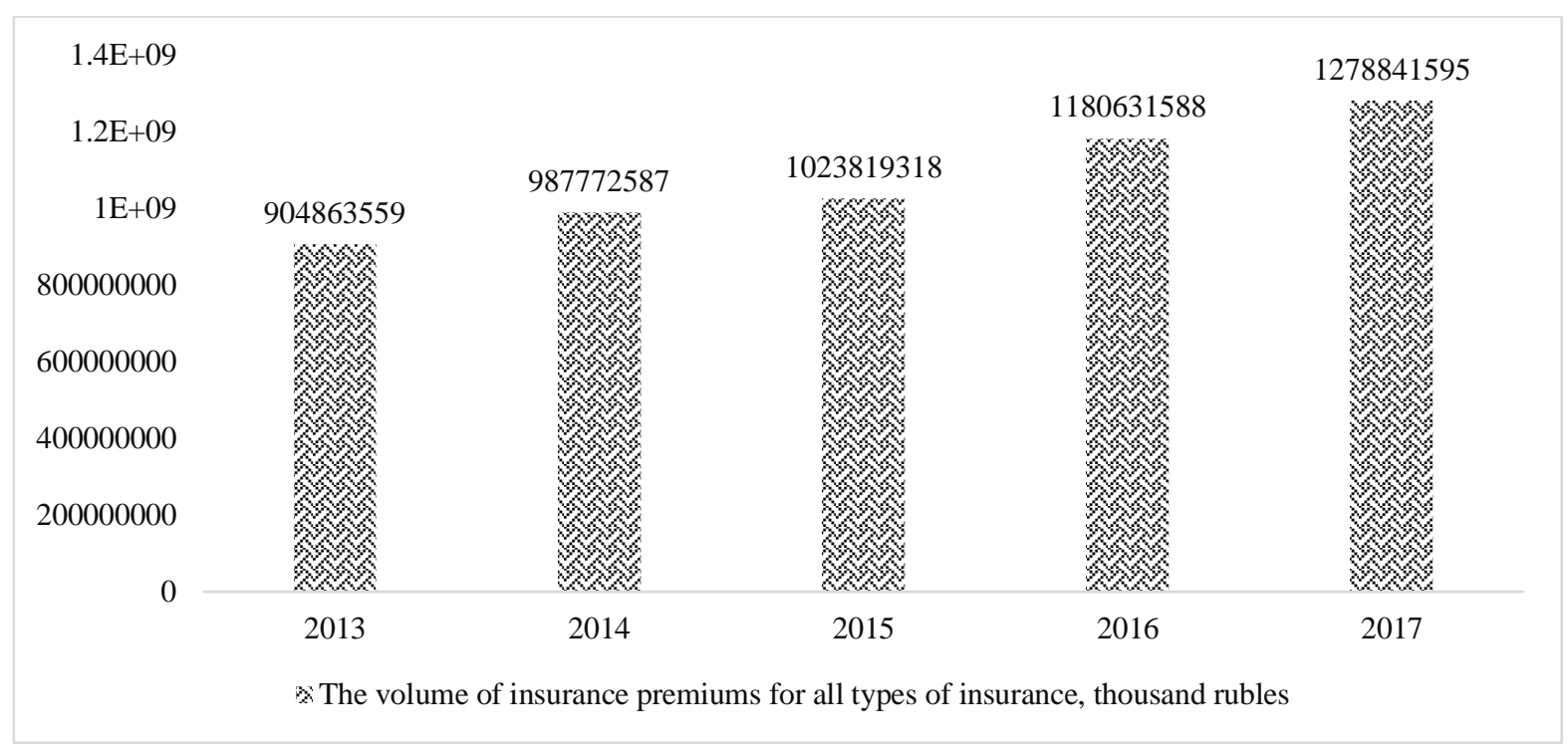

Figure 1: The volume of insurance premiums for all types of insurance in Russia for 2013-2017, thousand rubles Source: compiled by the authors based on $[9,28]$ 


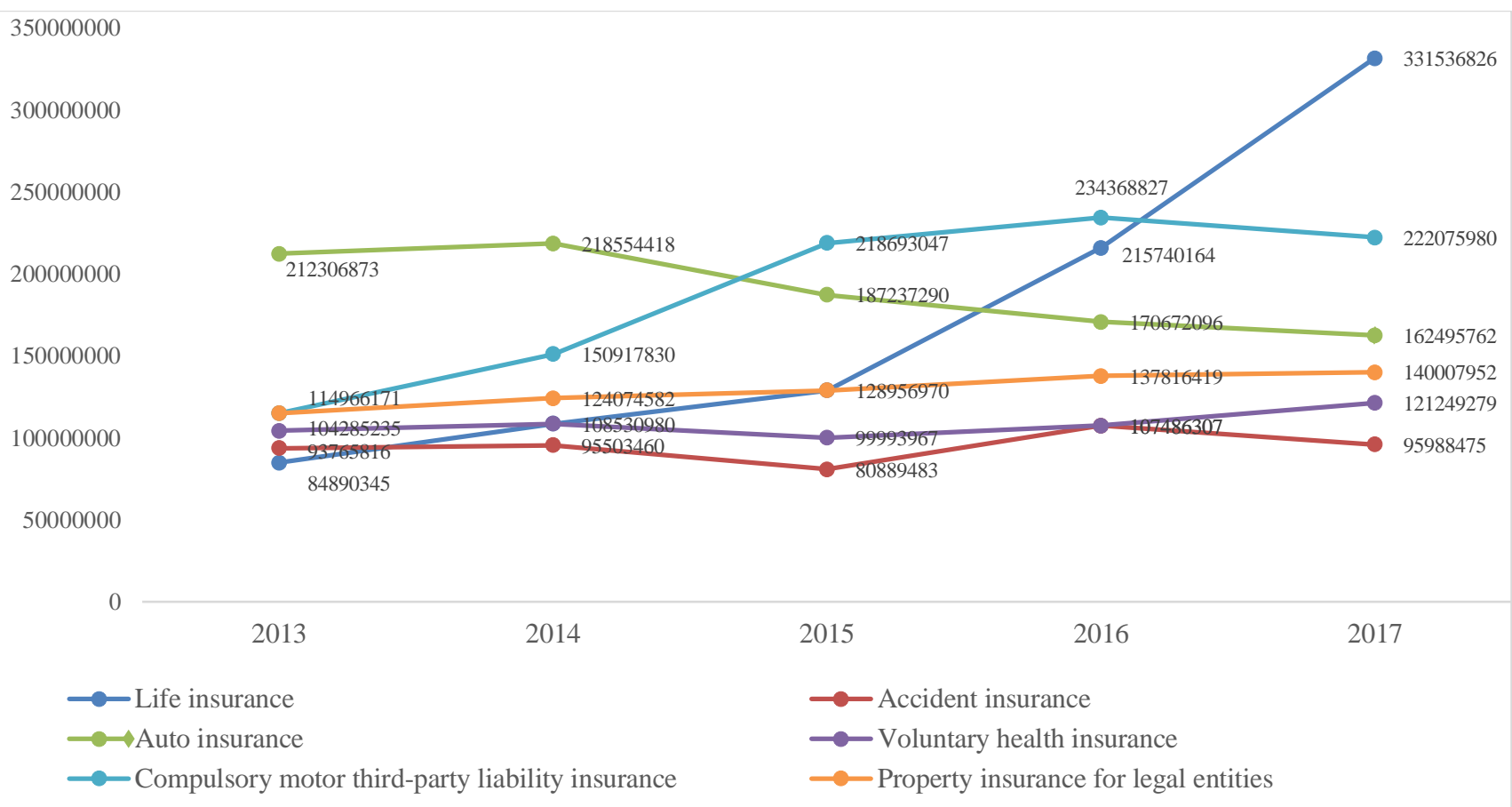

Figure 2: Dynamics of insurance premiums by type of insurance in Russia for 2013-2017

Source: compiled by the authors based on $[9,28]$

In Figure 3, we see that auto insurance (CASCO) insurance had the largest market share and its share reached $23.46 \%$ in 2013. It should be noted that a significant share was also made by such types of insurance as compulsory motor third-party liability insurance $(14.84 \%)$, voluntary medical insurance $(12.71 \%)$; property insurance for legal entities $(11.52 \%)$, and accident insurance $(10.36 \%)$ and life insurance $(9.38 \%)$; the remaining premiums by type of insurance in 2013 did not exceed $4 \%$ of the insurance market.

The situation has changed significantly over the next four years (period from 2014 to 2017). Life insurance had outstripping investment growth compared to all other types of insurance; this growth brought not only leaders, but also provided a leading position in the structure of the insurance market. Accordingly, the share of leaders of previous periods was declining, such as property insurance, hull insurance and compulsory motor liability insurance, which, together with maintaining low indicators of development of liability insurance and business risks, reflected the general slowdown in the growth of industrial production and investment in the national economy. Life insurance occupies the largest share at the end of 2017. The share of premiums for this type increased by $7.66 \mathrm{pp}$ compared to 2016 and amounted to $25.93 \%$. In addition, the share of accident insurance premiums increased and amounted to $9.48 \%$ in 2017 . The share of OSAGO insurance premiums in 2017 compared to 2016 decreased by 2.48 percentage points and amounted to $17.37 \%$. The share of CASCO insurance premiums decreased, which amounted to only $12.71 \%$ in 2017. Property insurance premiums also decreased and amounted to $7.51 \%$. The share of premiums for other types of insurance did not change significantly in 2017 compared to 2016. The number of insurance companies in the insurance market decreased by 30 (including 8 compulsory health insurance insurers) in 2017. As a result, 222 insurance and 4 specialized reinsurance companies remained on the market, registered in 37 constituent entities of the Russian Federation at the end of 2017.

\section{The results discussion}

The analysis of the features of the insurance business in Russia allows us to identify the main factors that hinder the development of the insurance market. They have a character both intra systemic and related to the characteristics of the Russian economy. These factors include: (a) poor efficiency of the current regulatory and regulatory in the field of insurance; (b) insufficient level of economic opportunities of insurance entities; (c) low solvent demand for insurance services from the population and enterprises; (d) absence of new distribution channels and areas for improving the quality of sales of insurance products; (e) high degree of concentration of the insurance market and the monopolization of insurance services; (f) existing discrepancies with the requirements for solvency of insurers established by international standards; and (g) fraud in the insurance market and unfair competition. Let us present the main problems of the Russian market of insurance services and ways to solve them in the form of a table (Table 1). Examined the problems and prospects for the development of the Russian insurance market, we note that the domestic market is developing even in difficult economic conditions, it given great importance by the state, as evidenced by frequent amendments to the regulatory and legal framework of insurance, and more active participation of the state in the regulation of insurance activities. Therefore, despite the problems in the development of the insurance market, it has prospects for further improvement. 


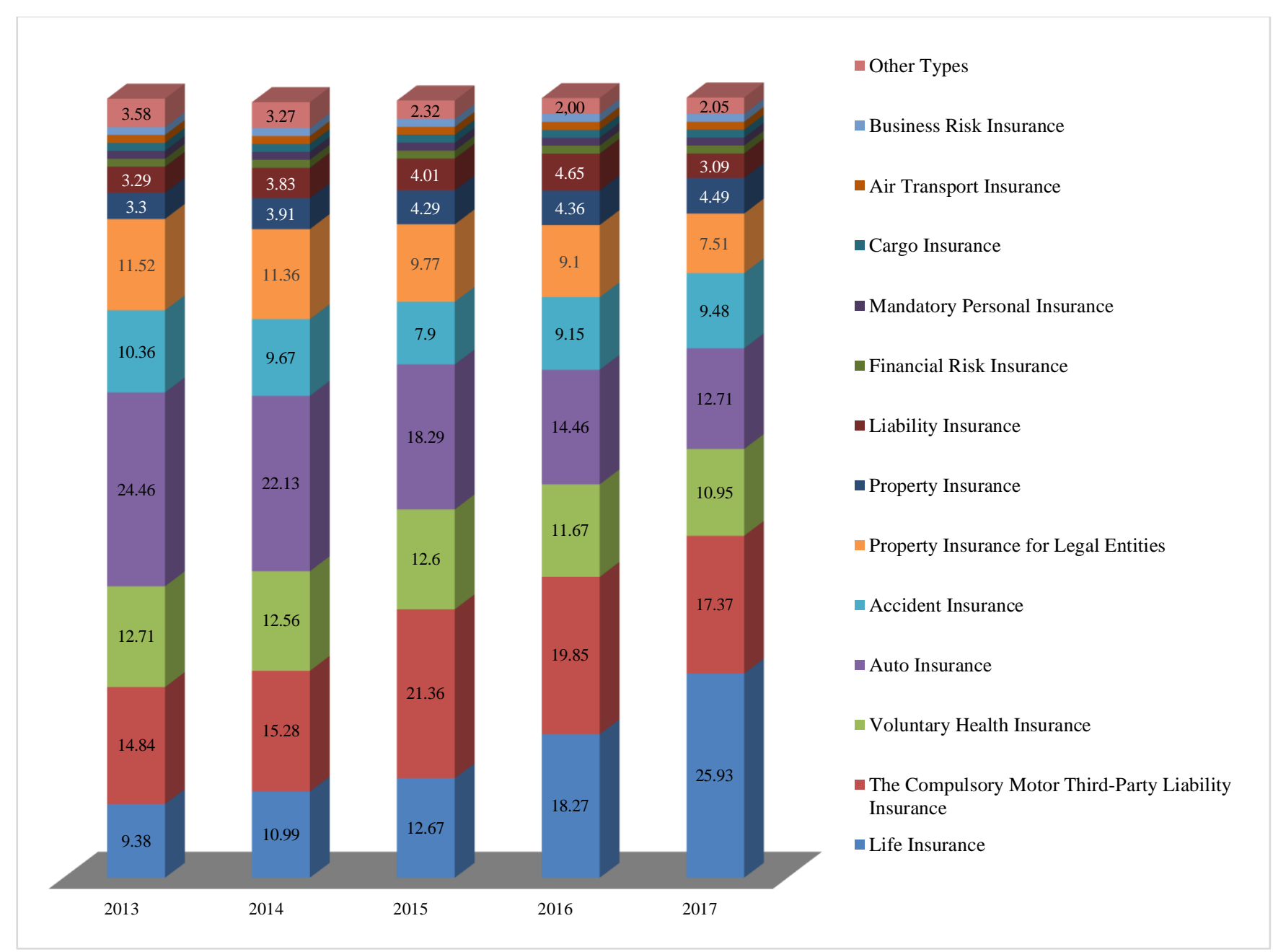

Figure 3: The share of insurance premiums by type of insurance in Russia for 2013-2017 (Source: compiled by the authors based on [9, 28])

The official data of the Bank of Russia on the dynamics of the insurance market in 2018 show that dynamic growth has continued, its pace has been the highest over the past 5 years, almost 8 times higher than GDP growth and amounted to $15.7 \%$. $[33,34]$ High growth of insurance fees, a significant decrease in the level of loss of insurance operations and good investment results allowed insurers to almost double (96.3\%) the amount of their annual profit (ibid., p. 24). Personal insurance remained the main driver of growth, as in previous years; however, an intra sectoral shift in priorities outlined. The highest results were shown in accident and illness insurance (an increase of 39.8\%), which, together with an increase in the life insurance of borrowers (by $31.4 \%$ ), is characterized by a shift in the focus of the insurance business from investment life insurance to the field of life and health risks persons upon receipt of consumer or mortgage loans. Once again, the market showed an increase in CASCO insurance premiums (by 3.8\%), however, solvent demand from the population for car insurance again declined $(-0.7 \%)$. A trend in the stagnation of the economy also turned out to be the trend of a continuing decline in fees in property insurance of legal entities $(-7.8 \%)$.

The high probability of stagnation and even recession of the insurance market is largely logical in the near future; as world experience shows that insurance develop steadily and rapidly in the context of high rates of economic growth, population incomes and an influx of significant investment volumes. The rapid growth of the insurance market was unprecedented until 2019; this due to the fact that financial intermediaries redirected significant investment flows from the banking sector to the insurance sector, which was not caused by the objective needs of the economy. In the forecast period, the growth of the insurance market will carried out mainly due to the growth in demand for personal insurance, associated not only with investments, but also with the provision of credit services and corporate social risk insurance. The smallest growth expected in the mandatory car insurance sector (Table 2). 
Table 1: Problems of development of the insurance market in the Russian Federation and solutions way

\begin{tabular}{|c|c|}
\hline Insurance market problem & Solution method \\
\hline $\begin{array}{l}\text { Low level of demand and unpreparedness of the population to accept } \\
\text { insurance services; limited supply of insurance services targeted at } \\
\text { various categories of consumers; low level of trust of insurers in insurers } \\
\text { and in the insurance mechanism in general }\end{array}$ & $\begin{array}{l}\text { A. Promotion of insurance knowledge in the community } \\
\text { B. Formation of insurance culture among citizens }\end{array}$ \\
\hline Disagreements and contradictions in the insurance legislation & Improving the provisions of existing legislation governing insurance \\
\hline Lack of qualified specialists & $\begin{array}{l}\text { A. Training of specialists, creation of structures engaged in training and } \\
\text { education } \\
\text { B. Work in the field of personnel policy }\end{array}$ \\
\hline Inadequate supervisory activity of the Central Bank & $\begin{array}{l}\text { A. Strengthening government regulation in relation to the activities of } \\
\text { insurance companies } \\
\text { B. Improving the regulation of compulsory insurance. } \\
\text { State regulation of the minimum and maximum values of insurance tariffs } \\
\text { is necessary; development of a procedure for monitoring the applicable } \\
\text { insurance rates, their validity and bringing its results to the public; } \\
\text { consistent unification of the procedure for determining the amount of } \\
\text { damage and insurance compensation for compulsory types of insurance. }\end{array}$ \\
\hline $\begin{array}{l}\text { Fraud, market opacity; the presence of non-competitive actions, as well as } \\
\text { a high level of concentration in the insurance services market; neglect of } \\
\text { the rights and legitimate interests of policyholders by individual insurers }\end{array}$ & $\begin{array}{l}\text { A. Development of additional security departments in insurance } \\
\text { companies that develop their own limiters to reduce fraud in their } \\
\text { insurance systems } \\
\text { B. Introduction of additional liability measures for violation of the rights } \\
\text { of policyholders }\end{array}$ \\
\hline $\begin{array}{l}\text { Low standards of activity; a decrease in the quality of fulfillment of } \\
\text { obligations by insurers under insurance contracts to policyholders; low } \\
\text { level of intermediary services to consumers }\end{array}$ & $\begin{array}{l}\text { Expansion of the scope of insurance entities. Development of the } \\
\text { insurance market infrastructure. } \\
\text { Improving the stability and reliability of the insurance market } \\
\text { infrastructure, as well as the efficiency and effectiveness of its activities, } \\
\text { requires the implementation of a range of measures, in particular: } \\
\text { development of the institution of insurance brokers and insurance agents; } \\
\text { legislative regulation of actuarial activities, the formation of the institute } \\
\text { of insurance actuaries, etc. }\end{array}$ \\
\hline
\end{tabular}

Source: compiled by the authors based on $[44,45]$

Table 2: Forecast of the dynamics of the insurance market and its individual segments

\begin{tabular}{|c|c|c|c|c|c|c|}
\hline Insurance type & $\begin{array}{l}\text { Prizes, 2017, } \\
\text { billion } \\
\text { rubles. }\end{array}$ & $\begin{array}{l}\text { Prizes, } \\
2018, \\
\text { billion } \\
\text { rubles. }\end{array}$ & $\begin{array}{c}\text { Assessment of } \\
\text { the growth } \\
\text { rate of } \\
\text { contributions, } \\
2018 / 2017, \%\end{array}$ & $\begin{array}{l}\text { Prizes, } \\
2019, \\
\text { billion } \\
\text { rubles. }\end{array}$ & $\begin{array}{c}\begin{array}{c}\text { Growth rate } \\
\text { of } \\
\text { contributions, } \\
2019 / 2018, \%\end{array} \mid \\
\end{array}$ & Key factors influencing the forecast \\
\hline \multirow[b]{2}{*}{ Life insurance } & \multirow[b]{2}{*}{332} & \multirow[b]{2}{*}{450} & \multirow[b]{2}{*}{36} & 575 & 28 & $\begin{array}{l}\text { Scenario 1: premium growth supported by further intensive sales } \\
\text { of LIS by credit institutions and relatively low deposit rates. }\end{array}$ \\
\hline & & & & 350 & $-20-25$ & $\begin{array}{l}\text { Scenario 2: the pressure exerted by the overflow of customer } \\
\text { funds to other financial instruments; it is a result of the } \\
\text { introduction of basic standards for the implementation of sales of } \\
\text { LIS (including regulatory restrictive measures). }\end{array}$ \\
\hline $\begin{array}{l}\text { Accident and Health } \\
\text { Insurance }\end{array}$ & 121 & 140 & 16 & 155 & $10-11$ & $\begin{array}{l}\text { Slowdown in growth is a result of increased interest rates on } \\
\text { loans, the instability of tourist flow due to the volatility of } \\
\text { exchange rates. }\end{array}$ \\
\hline $\begin{array}{l}\text { Voluntary health } \\
\text { insurance }\end{array}$ & 140 & 150 & 7 & 160 & $6-7$ & $\begin{array}{l}\text { Support provide by inflation of the cost of services of medical } \\
\text { institutions, the popularization of critical illness insurance } \\
\text { programs, and the development of telemedicine. }\end{array}$ \\
\hline Motor hull insurance & 162 & 165 & 2 & 165 & 0 & $\begin{array}{l}\text { Stagnation is a result of increased interest rates on loans, the } \\
\text { expected slowdown in new car sales and the saturation of the } \\
\text { segment with truncated insurance programs and franchised } \\
\text { policies. }\end{array}$ \\
\hline $\begin{array}{l}\text { Insurance of other } \\
\text { property of legal } \\
\text { entities }\end{array}$ & 96 & 90 & (6) & 95 & $5-6$ & Small market recovery after contraction in 2017 and 2018. \\
\hline Property Insurance & 57 & 63 & 10 & 69 & $9-10$ & $\begin{array}{l}\text { Growth drivers -are "boxed" standard products and cooperation } \\
\text { with banks. }\end{array}$ \\
\hline OSAGO & 222 & 222 & (0) & 226 & $1-2$ & $\begin{array}{l}\text { Changes in the tariff corridor will not have a significant positive } \\
\text { impact on the dynamics of the volume of the OSAGO segment. }\end{array}$ \\
\hline $\begin{array}{l}\text { Insurance market } \\
\text { excluding life } \\
\text { insurance, total }\end{array}$ & 947 & 990 & $4-5$ & $\begin{array}{c}1020- \\
1040\end{array}$ & $3-5$ & \\
\hline
\end{tabular}

Source: compiled by the authors based on [28] 
The Strategy for the development of insurance activity of the Russian Federation until 2020, approved by the Government, is effective for the implementation of the insurance industry development directions. In order to advance the insurance sector to a strategically significant level, the following measures identified. First, improving regulation of compulsory insurance; stimulating the development of voluntary insurance. Second, the scope of activities of insurance entities expanding. Third, the optimization of the risk management system with the involvement of budget funds; forth, the development of agricultural insurance system; fifth, increasing the effectiveness of forms and methods of state control and supervision of insurance entities and ensuring their financial stability, as well as strengthening the role of the Russian insurance market at the international level [35-37].

\section{Conclusion}

Currently, under this strategy, an active reform of the Russian insurance market is underway, but due to the crisis processes in the economy, the implementation of its measures in full is somewhat difficult. The conjuncture of the insurance market is quite sensitive to economic fluctuations; therefore, in the future its development will also depend on economic and political factors, external and internal threats. The solution of many issues is the use of block chain technologies. At the same time, pilot implementation with subsequent scaling is required and directly legal regulation of digital innovations in Russia. Further research needs to optimize the budget risk management in the context of digitalization.

\section{Aknowledgment}

The study was carried out with the financial support of the Russian Science Foundation within the framework of the scientific project "Interaction of social institutions as the basis of Russia's economic security in the context of globalization".

\section{Ethical issue}

Authors are aware of, and comply with, best practice in publication ethics specifically with regard to authorship (avoidance of guest authorship), dual submission, manipulation of figures, competing interests and compliance with policies on research ethics. Authors adhere to publication requirements that submitted work is original and has not been published elsewhere in any language.

\section{Competing interests}

The authors declare that there is no conflict of interest that would prejudice the impartiality of this scientific work.

\section{Authors' contribution}

All authors of this study have a complete contribution for data collection, data analyses and manuscript writing.

\section{References}

[1] Bodner GD, Antonenko DI. The current state and problems of the development of CTP in the Russian Federation. Scientific Bulletin: finance, banks, investment. 2015; 4(33):111-116.

[2] Vorobyov YuN, Vorobyova EI. Evaluation of insurance companies Scientific Bulletin: Finance, Banks, Investments. 2016; 3(36):53-63.
[3] Melnik NA, Chagli AI. Auto insurance in the portfolio of insurance companies. Scientific Bulletin: Finance, Banks, Investments. 2017; 2(39):56-60.

[4] Ermolenko GG, Mashyanova EE. Optimization of the capital structure of insurance organizations. Scientific Bulletin: finance, banks, investment. 2018; 3(43):49-56.

[5] Vorobyov YuN, Vorobyova EI. Pension insurance in Russia Scientific Bulletin: Finance, Banks, Investments. 2018; 3(44):45-57.

[6] Borsch L, Burkaltseva D, Vorobyov Yu, Vorobyova E, Chepurko, V. Dichotomy or unification of contrasts of the market and capitalism: Forecast and plan (part 1). International Journal of Economic Research. 2016; 13(9):3775-3787.

[7] Borsch L, Burkaltseva D, Vorobyov Yu, Vorobyeva E, Chepurko V. Dichotomy or unification of contrasts of the market and capitalism: Forecast and plan (part 2). International Journal of Economic Research. 13(9):3789-3801.

[8] Nikitina MG, Pobirchenko VV, Shutaieva EA, Karlova AI. The investment component in a nation's economic security: the case of the Russian Federation. Entrepreneurship and sustainability issues. 2018;.6(2):958-967. Available from: DOI: 10.9770/jesi.2018.6.2(32)

[9] Nikitina MG, Pobirchenko VV, Shutaeva EA, Barsegyan AG, Dyatel VN, Abibullaev MS. Formation of the practice-oriented educational paradigm on the basis of the competence approach. Opcion. 2019; 35(S20):2348-2365.

[10]Ivanov PI, Burkaltseva DD, Arzumanov RM, Grischenko LL, Zhirnov YuN, Pestov NN, Oleynik AS, Uryadov YuYu. Risks and Legal Opportunities of National Projects: Modeling Security. International Journal of Innovative Technology and Exploring Engineering. 2019; 9(2):4266-4273.

[11]Burkaltseva D, Vorobyov Yu, Borsh L, Gerasimova S, Chepurko V. Structural modelling the system of ensuring the economic security of the complex territorial socio-economic system of the eurasec. International Journal of Applied Business and Economic Research 2016; 14(9):5683-5704

[12] Burkaltseva DD, Tsohla SYu, Guk OA, Borovskaia LV, Bondar AP. Basic forms of institutional changes of economy in Russia. International Journal of Applied Business and Economic Research 2016; 14(15):11137-11152.

[13] Burkaltseva DD, Voronin IN, Lisitsky AM, Mazur NM, Guk OA Assessing the Effects of Investments Into Innovative Activity as a Regional Competitiveness Factor. International Journal of Applied Business and Economic Research. 2017; 15(8):11-27.

[14] Burkaltseva DD, Borsch LM, Blazhevich OG, Frolova EE, Labonin IV. Financial and economic security of business as a primary element in the economic system. Revista Espacios. 2017; 38(33):3.

[15] Sivash OS, Burkaltseva DD, Ushakov DS. Activization of Investment Process in the Agrarian Sector. International Journal of Ecology and Development. 2017; 32(4):169-182.

[16] Vorobyov YuN, Burkaltseva DD, Kovalyova IN, Borsch LM, Gerasimova SV. Sustainable Development of the Regional Economy: Indicators, Analysis, Systematization. Journal of Advanced Research in Law and Economics. 2018; 9(2):729-739.

[17] Burkaltseva DD, Betskov AV, Kilyaskhanov HSh, Demin GI, Grischenko LL, Timoshenko OE, Tyulin AS. Psychological Features of Cybercriminal Behavior in Committing Financial Crimes under Conditions of Digital Transformation of Socioeconomic Systems Opción. 2018; 34(85):1642-1653.

[18]Burkaltseva DD, Betskov AV, Kilyaskhanov HSh, Demin GI, Grischenko LL, Timoshenko OE, Tyulin AS. Psychology of Criminal In Conditions Of Socioeconomic System Transformation. Opcion. 2019; 35(SI19):2872-2882.

[19] Klimchuk SV, Sivash OS, Burkaltseva DD, Nekhaychuk DV, Gurova VA, Kilyaskhanov HSh, Zotova SA. Time Lag in the System of Financial Transformations. International Journal of Recent Technology and Engineering. 2019; 8(3):40-45. Available from: DOI: $10.35940 /$ ijrte.C3869.098319

[20] Gerasimova S, Burkaltseva D, Borsch L, Apatova N, Vorobyova E, Zharova A, Ivanov S, Zaytseva I. Multi-level transformation 
processes: digital technologies in the economy. International Journal of Innovative Technology and Exploring Engineering. 2019; 8(12):419-425.

[21] Korobeynikova OM, Korobeynikov DA, Popova LV. Scenarios of digital innovation of the payment market in Russia. In: Advances in Social Science, Education and Humanities Research. Vol. 240. Proceedings of the 2nd International Scientific conference on New Industrialization: Global, national, regional dimension (SICNI 2018), St. Petersburg, Russia, October 26-27, 2018. St. Petersburg: Atlantis Press; 2018. p. 174-178. Available from: https://www.atlantispress.com/proceedings/sicni-18/55911830

[22] Vorobyova E, Burkaltseva D, Borsch L, Blazhevich O, Guk O, Shalneva V, Kilyaskhanov H, Zotova S. Calculation of Indicators of Investment Attractiveness of the Region. International Journal on Emerging Technologies. 2019; 10(3):69-76.

[23] Burkaltseva DD, Borsch LM, Blazhevich OG, Frolova EE, Labonin IV. Financial and economic security of business as a primary element in the economic system. Revista Espacios. 2017; 38(33):3.

[24]Burkaltseva DD, Voronin IN, Lisitsky AM, Mazur NM, Guk OA. Assessing the Effects of Investments Into Innovative Activity as a Regional Competitiveness Factor. International Journal of Applied Business and Economic Research. 2017; 15(8):11-27.

[25]Blazhevich OG, Burkaltseva DD, Shalneva VV, Betskov AV, Kilyaskhanov HSh, Bondar AP, Zotova SA. Assessment of financial security in the chemical industry of the Republic of Crimea. Journal of Pharmaceutical Sciences and Research. 2018; 10(6):1377-1385.

[26] Jallal MAK, Burkaltseva D, Vorobyova E, Apatova N, Blazhevich O, Betskov A, Kilyaskhanov H, Shcheglova S, Mosina I. Development of the Crimean Agriculture. International Journal of Innovative Technology and Exploring Engineering. 2019; 9(2):1644-1661. Available from: DOI: 10.35940/ijitee.B7650.129219

[27] Gerasimova S, Zaytseva I, Burkaltseva D, Borsch L, Apatova N, Vorobyova E, Zharova A, Ivanov S. Multi-Level Transformation Processes: Digital Technologies in the Economy. International Journal of Innovative Technology and Exploring Engineering. 2019; 8(12):419-425. Available from: DOI: 10.35940/ijitee.L3315.1081219

[28]Central Bank of the Russian Federation. Available from: http://www.cbr.ru/

[29] Insurance today. Available from: http://www.insurinfo.ru/statistics/analytics

[30] Knyazeva EG, Yuzvovich LI, Smorodina EA, Pavlenko AO. Russian insurance market: modern development challenges. Fundamental'nyye issledovaniya [Basic research]. 2015; 3:181-186.

[31] Klerk. Directions for the development of insurance until 2020; 2013. Available from: http://www.klerk.ru/boss/articles/343309/

[32] Insurance Help Portal. Available from: http://risk-insurance.ru

[33] Insurance News Agency. Available from: http://www.asn-news.ru

[34] Abibullaev MS, Shcheglova SS. Insurance of property of 1 Abibullaev MS, Shcheglova SS. Insurance of property of individuals: current state and development prospects in the Russian Federation. Scientific Bulletin: finance, banks, investments. 2018; 1(42):75-81

[35] Scheglova SS, Kondratieva AS. Assessment of the current state of the sphere of compulsory medical insurance in the Russian Federation. Scientific Bulletin: finance, banks, investment. 2016; 3(36):71-76. 